\title{
Scoping Review: Autism Research in Baltic States-What Is Known and What Is Still To Be Studied
}

\author{
Ruta Buivydaite $^{1} \cdot$ Charles R. Newton $^{1} \cdot$ Audrone Prasauskiene $^{2}$
}

Received: 24 February 2017 / Accepted: 5 August 2017 /Published online: 5 September 2017

(C) The Author(s) 2017. This article is an open access publication

\begin{abstract}
We conducted a scoping review of the current knowledge about autism in Baltic States: Lithuania, Latvia and Estonia. The aim was to identify publications about autism and potential gaps of knowledge in this region. The search was conducted on March 31, 2016 using PubMed, PsycINFO and EMBASE databases. The search was updated on August 31, 2016; a total of 47 studies were analysed. Current research on autism in Baltic States is still in its beginning. Areas studied were education, medicine, parenting, autism in adulthood, treatments and epidemiology. Education sector is the most researched discipline about autism in Baltic countries especially addressing issue on schooling practices for autistic children. The prevalence of autism is unclear as only one outdated epidemiological study was found. Further epidemiological, clinical intervention research need to be conducted in this region.
\end{abstract}

Keywords Autism $\cdot$ ASD $\cdot$ Lithuania $\cdot$ Latvia $\cdot$ Estonia $\cdot$ Research

Little is known about the current situation of autism in Baltic States as there is a lack of substantial research in this field across all three Baltic countries (Pūras et al. 2004; Querdenker and Meirhofer 2014; Mikulènaite and Ulevičiūte 2004). Therefore, to investigate autism in this region, we decided to perform scoping review.

Ruta Buivydaite

ruta.buivydaite@psych.ox.ac.uk

1 Department of Psychiatry, University of Oxford, Warneford Hospital, Oxford OX3 7JX, UK

2 Department of Health Sciences, Lithuanian University of Health, Lopšelio g. 10, LT 47179 Kaunas, Lithuania
As part of the post-Soviet communist bloc, Estonia, Latvia and Lithuania all gained independence in 1990s (Slay 2009). With independence and sovereignty, economic, political and social sectors underwent significant changes. The post-Soviet countries moved from centrally planned economies ${ }^{1}$ to capitalism, from autocracy to democracy and from social 'equality' to equity (Slay 2009). The existing view of mental health of that time was highly influenced by Moscow school of psychiatry, which concentrated on treatment with medicine and institutionalisation of patients with psychiatric disorders (Lesinskienè et al. 2008). Government did not recognise mental health problems and did not seek to integrate vulnerable people into society (Pūras et al. 2004). Moreover, treatment relied on a biological approach, with few nonpharmacological therapies offered. In addition, there was no family care or support provided by the government (Lesinskienè et al. 2008; Pūras et al. 2004).

Since the 1990s when the three Baltic countries gained independence, there appears to have been little change in the management of autism (Pūras et al. 2004; Querdenker and Meirhofer 2014). This may be caused by lack of awareness and comprehension of the condition, which is supported by the absence of integration of people with autism into regular schools. Although most health care professionals recognise autism and the diagnosis is made, few intervention programs have been introduced. Applied Behavioural Analysis (ABA) and Treatment and Education of Autistic and Communicationrelated handicapped Children (TEACCH) are the main intervention programs introduced for the parents, but the access is limited due to costs of services and lack of expertise in their administration in the Baltic countries (Krasauskaite 2010;

\footnotetext{
1 "An economic system in which economic decisions are made by the state or government rather than by interaction between consumers and businesses" (Slay 2009).
} 
Querdenker and Meirhofer 2014). According to Mansell and Morris (2004) 'ABA is a process of modifying behaviour using antecedent stimuli and consequences'. Virues-Ortega et al. (2013) defined TEACCH as 'an intervention program designed to assess and enhance individual's abilities and skills'. Both programs are designed to help people with autism spectrum disorder.

The current scoping review was conducted with the aims to

i) Describe the scope (i.e. amount, focus and nature) of research on autism across Baltic countries;

ii) Summarise and disseminate main findings, settings and methodology across Baltic countries;

iii) To identify the research gaps in the autism research across Baltic States.

\section{Methods}

The goal was to identify, retrieve and summarise the existing knowledge on autism in Baltic countries. The scoping review was chosen as main method for analysis because it is broader and more inclusive and it provides summaries of research findings more than the methods used to obtain them. The main phases of this scoping review were:

- $\quad$ Searching for relevant studies;

- Selecting studies based on pre-defined inclusion criteria;

- Extracting data;

- Collecting, summarising and reporting the results.

\section{Data Sources and Search Strategy}

The initial search was implemented on March 31, 2016, in three electronic databases PubMed (Medical Sciences, 1964-March 31, 2016), PsychINFO (Behavioural And Social Sciences 1966-March 31, 2016) and EBSCO (Multidisciplinary, 1900-March 31, 2016). Update search was conducted on August 31, 2016, when additional 17 studies were included.

These databases were chosen for a broad range and more inclusive studies across different disciplines. The search engine consists of the key terms: autism spectrum disorder and the countries name. Total of 67 articles in all the databases were found. After duplicates were deleted and the articles abstracts were read based on relevance of the study, only 10 articles remained. This small number of articles about autism in Baltic States in the databases suggests a low level of research on autism in the Baltic countries. Most of the studies are published under state universities that the researcher is affiliated with; therefore, articles are held in the university electronic catalogue. In addition, majority of research in Eastern Europe is published in the language of the country it was performed and rarely translated into English language for international publication. The current study used Lithuanian, Latvian and Estonian national libraries and open access databases as also the databases of all universities in each country (Table 1).

The review was based on these search words: country, diagnosis and language. Article included patients with autism or people in close contact with patients like parents, teachers and siblings (Table 2). Studies were excluded if after reading the full text the study did not consist of any above-mentioned constructs. Lastly, if the study was found in couple of databases, only one paper was maintained.

\section{The Study Screening Process}

A two-stage process was used to scan the databases mentioned above. Firstly, title and abstracts of studies were reviewed to identify relevant studies ascending with searched constructs. The remaining articles were carefully read and full text analysis was performed. If the full text of the article was not available online, the author or university library was contacted for personal copy. If a copy was not obtained after that, article was excluded from the review. The remaining articles were reported in the results section of this scoping review (Fig. 1).

\section{Inter-Rater Reliability of Reviewers}

All papers were reviewed by two reviewers: A. Prasauskiene and R. Buivydaite, but kappa score was not extracted because of complexity of the data presented in the papers.

\section{Procedure of Text Analysis}

Each paper was read and the main findings of the paper were put in the Excel spreadsheet; then, the papers were grouped according to their topic. After thorough analysis of the grouped papers, the main findings emerged and were reported in the "Discussion" section.

\section{Results}

The results revealed that most of the research on autism started after 2005 , as only three studies were found on autism by that time. Most of the studies, $N=27$ were found in Lithuanian databases, $N=9$ studies in Estonian and $N=11$ studies in Latvian. Of the 15 unobtainable studies, 14 were from Latvia and one from Estonia. Majority of which consisted of Bachelor $(N=6)$ or Master $(N=8)$ thesis and $N=1$ journal 
Table 1 Country databases used in this review

\begin{tabular}{|c|c|c|}
\hline Country & Library name & URL \\
\hline \multirow[t]{3}{*}{ Lithuania } & Lituanistika & http://www.lvb.lt/primo_library/libweb/action/search.do \\
\hline & Libis (National Bibliographic data bank) & http://nbdb.libis.lt/ \\
\hline & Vilnius University & http://www.mb.vu.lt/istekliai \\
\hline \multirow[t]{2}{*}{ Latvia } & National Library of Latvia & http://www.lnb.lv/en/search \\
\hline & Riga University & http://www.rsu.lv/eng/services/library \\
\hline \multirow[t]{2}{*}{ Estonia } & National Library of Estonia & http://www.nlib.ee/en \\
\hline & University of Tartu Library & https://utlib.ut.ee/ \\
\hline
\end{tabular}

article. The types of publications were $45 \%$ of journal articles mainly published in local journals of medicine, health and education; remaining 55\% were thesis (Bachelor, Masters, Doctoral) submitted in final years of studies. Research methods used in the studies were mainly cross-sectional (46\%) comparing autism parents with parents of typically developing children or comparing children with autism with other children (typically developing or with developmental disorder); only few studies address questions of treatment and intervention for autism. Half of studies (51\%) used parents of children with autism or professionals as their primary participants and only one third of the participants in the studies were children. Only one study used autistic adults as research participants (Table 3 ).

\section{Discussion}

Autism is a relatively new diagnosis in the practice of psychiatry and medicine across all three Baltic countries. It was introduced only in the early 1990, after the Soviet Union collapsed (Pūras et al. 2004). This scoping review revealed that research on autism is limited. Areas studied in the Baltic States were education, medicine, parenting, autism in adulthood, treatments and epidemiology; however, quality of research in these areas were poor (Table 4).

Table 2 Constructs searched across databases

\begin{tabular}{lc}
\hline $\begin{array}{l}\text { Area of } \\
\text { interest }\end{array}$ & Construct's searched \\
\hline Country & $\begin{array}{c}\text { Lithuan*, Lietuv*, Leed*, Latvia, Latvij*, Läti, Estonia, } \\
\text { Esti*, Igauni*, Eest* }\end{array}$ \\
Diagnosis & $\begin{array}{c}\text { Autism, Autizm*, autism*, ASD, Autism Spectrum } \\
\text { Disorder, Autizmo Spektro Sutrikim*, Autism Spectrum } \\
\text { traucēj*, Autismi spektri hair*, Child Autism, Vaik* } \\
\text { autism*, Bērnu Autism, Lapse Autism, Visapusis raid* } \\
\text { sutrik*, Iespiedies attīstibas traucējumi, Läbivad arengu } \\
\text { häire }\end{array}$ \\
& $\begin{array}{c}\text { Lithuanian, Latvian, Estonian and English } \\
\text { Language }\end{array}$ \\
\hline
\end{tabular}

\section{Epidemiology}

This review revealed that the epidemiology of the autism in this region is still not clear as only one study attempted to estimate the prevalence across three Baltic States. It was conducted in 1999 in Lithuania. During this study, 6018 school children in 14 randomly selected secondary schools and 252 classes in Vilnius District (Lesinskienè 2000). Out of 133 children found with diagnosis, 36 cases of Asperger's, 38 cases of moderate autism and 59 cases of severe autism. Research was conducted 17 years ago and requires updated results with wider Lithuanian population (Lesinskiene 2000).

No epidemiological studies were found in Latvia or Estonia. Therefore, the question of amount of help needed for families remains unaddressed (Querdenker and Meirhofer 2014).

\section{Autism and Education}

Different measurements were used to assess children with autism. There were questionnaires designed by the researchers to measure individual accomplishments and social behaviours of autistic children in school setting. Also, prior validation or psychometric properties of the designed questionnaires were not presented (Astrauskiene 2008; Priede 2009; Terje 2013). Whilst PsychoEducational Profile (PEP) and Paediatric Evaluation of Disability Inventory (PEDI) tests were used to evaluate child's language and to assess independence skills, however, these tools were not validated in these populations (there were less studies assessing child's behaviour or well-being) (Kobolt 2010; Karen 2015; Tamošūniené et al. 2012).

The characteristics of autism were studied in parallel with schooling experiences especially with the importance of school integration compared with special schools. The questionnaires were used to evaluate the child's abilities when using group work (Priede 2009), individual programs (Terje 2013; Adomaitienė and Jurevičiūtė 2014), 


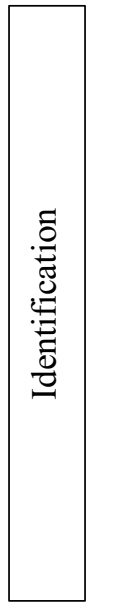

67 records found through the international databases PubMed $(n=13)$, PsycINFO $(n=38)$ and $\operatorname{EBSCO}(n=18)$.
537 Records were identified through Estonian $(\mathrm{n}=131)$, Latvian $(\mathrm{n}=171)$ and Lithuanian $(n=235)$ national libraries and university's databases.
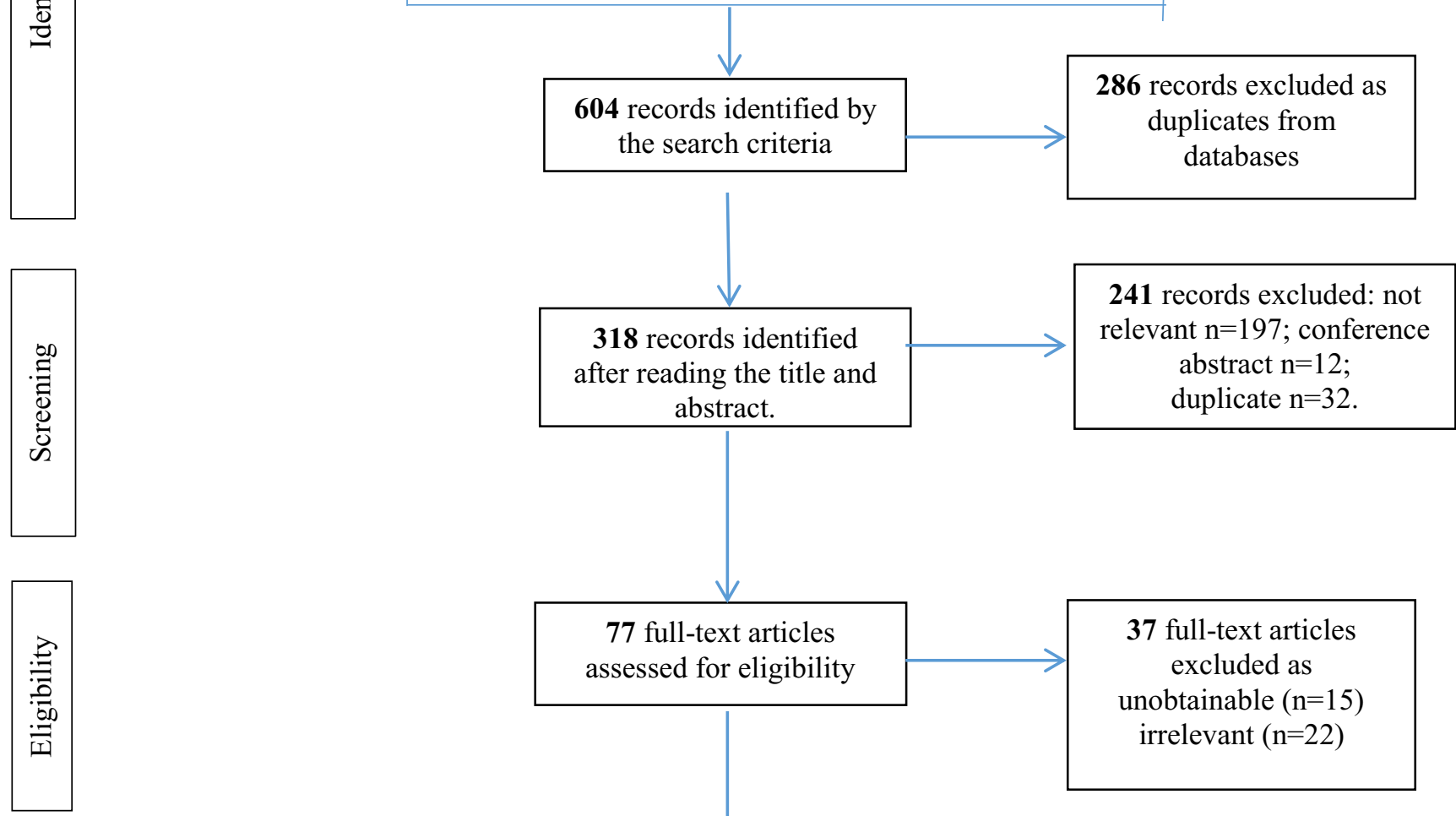

7 articles included in the review after August $31^{\text {st }}$, 2016

\section{7 articles included in the} review

37 full-text articles excluded as unobtainable $(\mathrm{n}=15)$ irrelevant $(n=22)$

Fig. 1 Flowchart of article extractions

mathematical lessons (Elis 2015) and socialisation programs (Lelde 2016). Review revealed that children learn social norms more effectively in regular schools than special schools (Astrauskienè 2008; Ivonytè et al. 2009; Priede 2009; Karen 2015; Žaromskytè 2012; Baškienè 2015; Lelde 2016). Other studies claimed that adapted or special programs are less stressing for the child and more productive in process (Dekšeniece 2012; Medvedeva 2012; Pociūtè 2012; Tamošūnienè et al. 2012; Terje 2013; Adomaitienè and Jurevičiūtė 2014; Sarmite 2014; Vilkelienè and Kondrotienè 2015). Other developmental problems of children with autism were not studied in the Baltic countries. There is still a need for more elaborate studies on understanding the relevant educational practices for autistic children in schools and teacher's experiences working with these children.

\section{Medical Research}

There were two genetic studies that concentrated on possible genetic causes of autism (Pentjuss et al. 2013; Bauze et al. 2014). And two studies concentrated on biological differences in autistic children (Kevere et al. 2009; Bauze et al. 2013a). One study compared frequency of hyperhomocysteinemia between schizophrenia and autism patients with results revealing that hyperhomocysteinemia is more common in autism than schizophrenia (Bauze et al. 2014). According to Guo et al. (2009), hyperhomocysteinemia is a 
Table 3 Demographics of the records

\begin{tabular}{|c|c|c|c|}
\hline Characteristics & Lithuania & Latvia & Estonia \\
\hline \multicolumn{4}{|l|}{ Publication year $(n)$} \\
\hline $2005<$ & 3 & 0 & 0 \\
\hline $2005-2010$ & 2 & 1 & 1 \\
\hline 2011-2014 & 11 & 4 & 6 \\
\hline 2015-March 31, 2016 & 3 & 0 & 2 \\
\hline March 31, 2016-August 31, 2016 & 7 & 6 & 0 \\
\hline \multicolumn{4}{|l|}{ Publication type $(n)$} \\
\hline Journal article & 17 & 3 & 0 \\
\hline Bachelor thesis & 0 & 5 & 5 \\
\hline Master thesis & 6 & 2 & 4 \\
\hline Doctoral thesis & 3 & 1 & 0 \\
\hline \multicolumn{4}{|l|}{ Research type $(n)$} \\
\hline Case study & 3 & 1 & 3 \\
\hline Cross-sectional & 12 & 6 & 3 \\
\hline Intervention & 1 & 0 & 1 \\
\hline Qualitative (interviews) & 6 & 1 & 1 \\
\hline Quasi-experimental & 0 & 1 & 1 \\
\hline Systematic review & 1 & 1 & 1 \\
\hline Mixed methods & 2 & 1 & 0 \\
\hline Epidemiological study & 1 & 0 & 0 \\
\hline \multicolumn{4}{|l|}{ Participants of the study $(n)$} \\
\hline Children with autism & 8 & 3 & 5 \\
\hline Adults with autism & 0 & 1 & 0 \\
\hline Parents of children with autism & 14 & 4 & 2 \\
\hline Professional working with people with autism & 0 & 1 & 0 \\
\hline Mixed group - parents and professionals & 3 & 1 & 1 \\
\hline
\end{tabular}

congenital condition with an abnormally high level of homocysteine in the blood. The homocysteine is responsible for the vitamin $\mathrm{B}_{6}, \mathrm{~B}_{9}$ and $\mathrm{B}_{12}$ production in the body (Miller et al. 1994). Other study concentrated on anthropometric parameters and found that patients with autism were taller in height compared to typically developing (Bauze et al. 2013a). Four studies underlined lack of studies in biomarkers of autism across Baltic countries.

The review also highlighted interest in research on diets and digestion for autistic children in Baltic States. The study by Lesinskiene (2002) showed that children with autism suffer from digestion problems compared to typically developing, which was highly correlated with poor sleep. Moreover, studies by Loonum and Veldemann (2013) as also by Oie (2014) informed that diet interventions like glutamine or casein free are common practices amongst parents of children with autism. Above findings showed that dietary treatments is used to influence on child's development and behaviour, which is a common finding in Western research (Emond et al. 2010; Whiteley et al. 2010).

The review found limited studies on experience of medical services for children with autism. The studies revealed lack of knowledge about autism amongst doctors in the emergency rooms (Lesinskienè et al. 2002b) and general practitioners (Pociūtè 2012). In addition, it highlighted the need to provide adapted medical services and home visits for families with autistic children (Lesinskienè et al. 2002a). These abovementioned studies revealed that medical personnel in Baltic countries require more teaching on autism and its characteristics as also attention to alternative ways of delivering treatment for these children.

\section{Parenting}

We found that there is interest in research on parent's mental health based on levels of stress, depression and anxiety. Results highlighted that parents of children with autism experienced statistically higher levels of stress, depression and anxiety compared with control groups (Matonyte 2005; Mickevičienè et al. 2009; Demčenko 2010; Stina 2013; Marii-Heleen 2014). In cross-sectional studies that compared parents of children with autism with parents of typically developing children, stress or depression were more common in those with autistic children and this correlated 


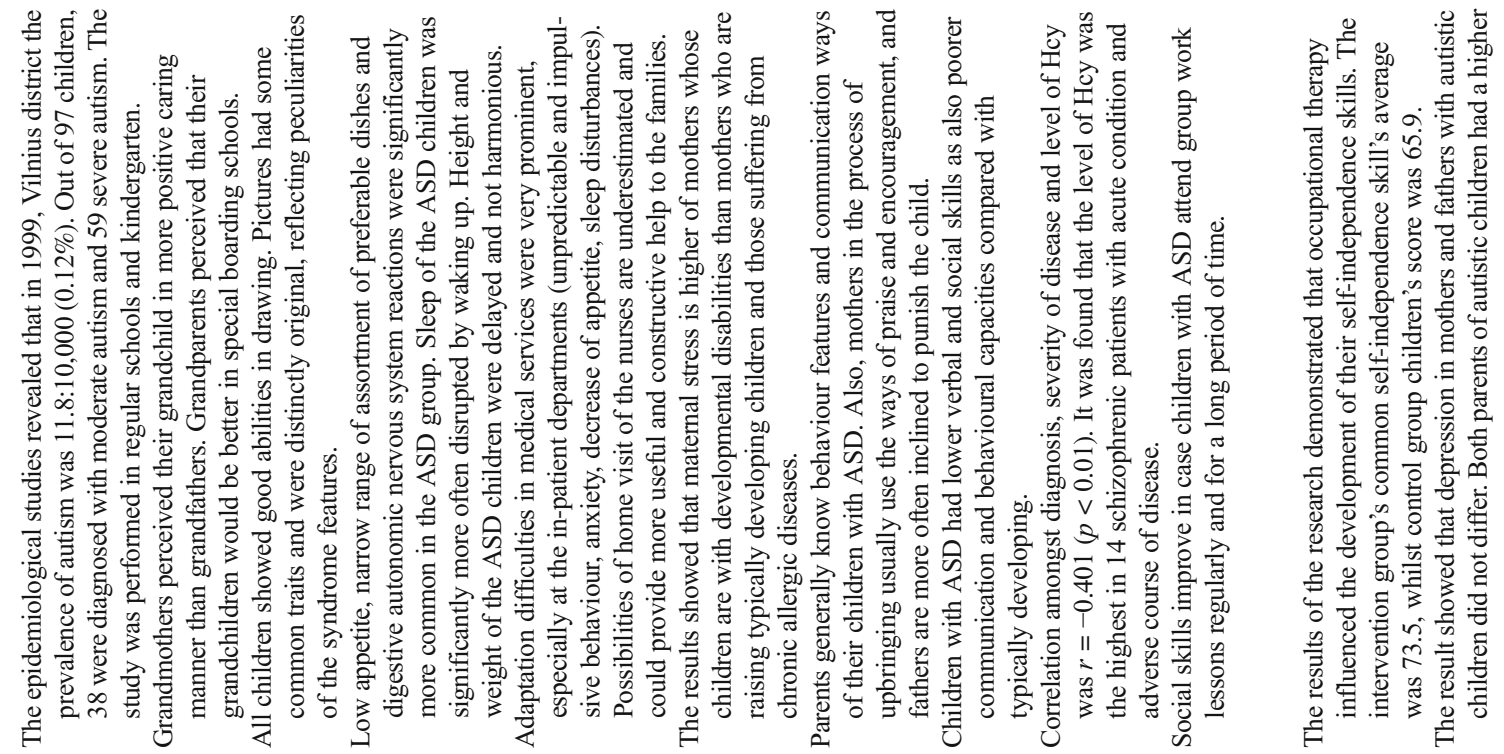

《र

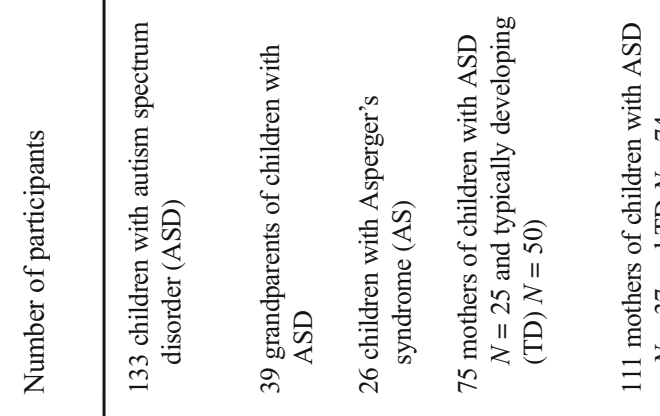

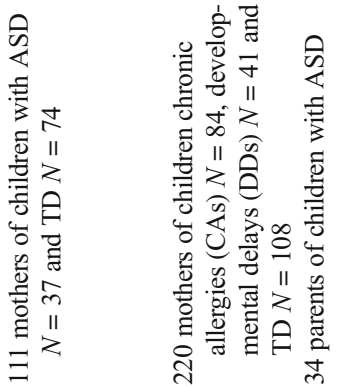

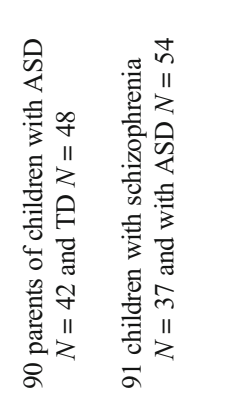

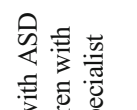

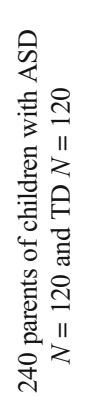

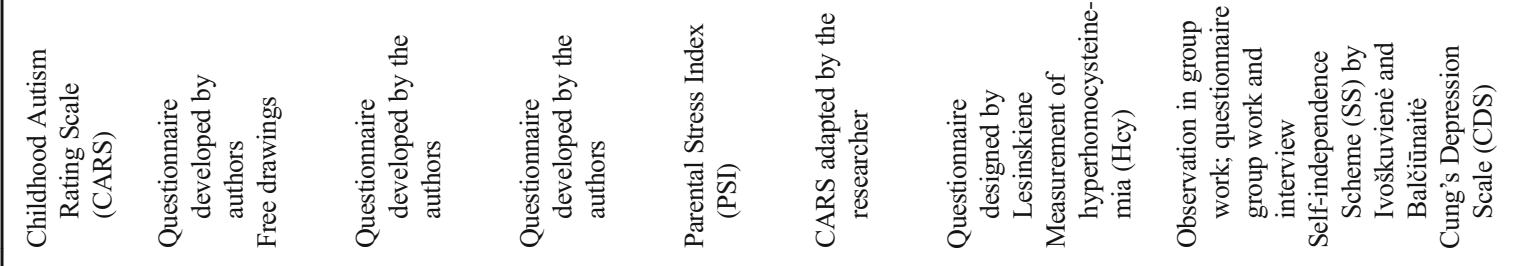

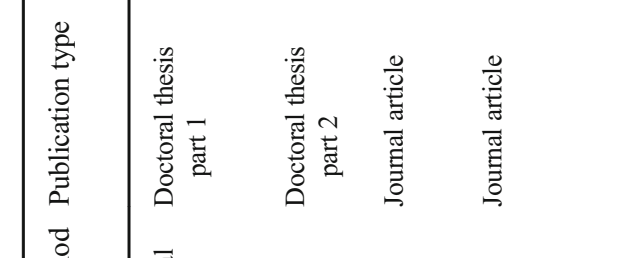

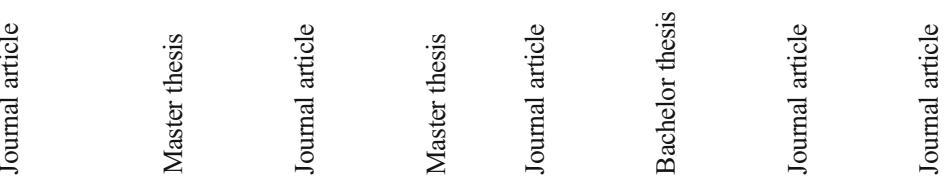

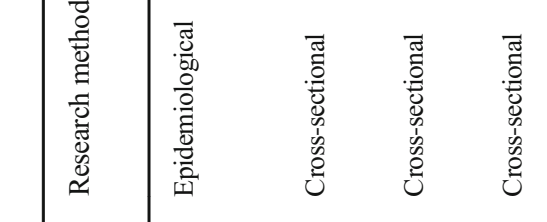

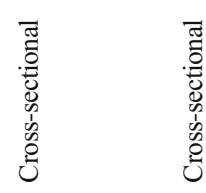

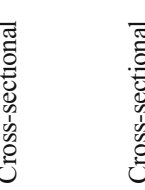

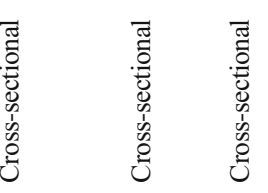

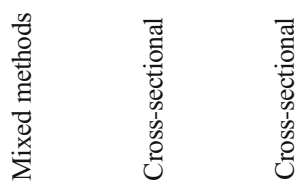

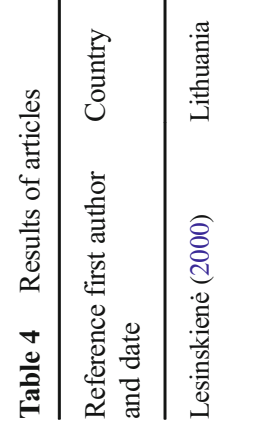

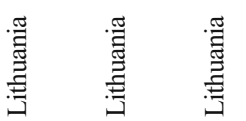

䔍

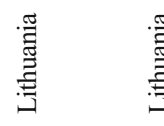

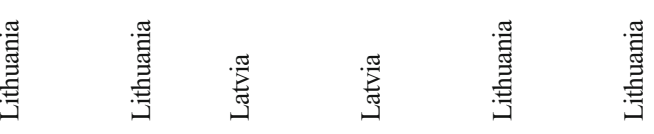

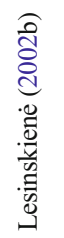

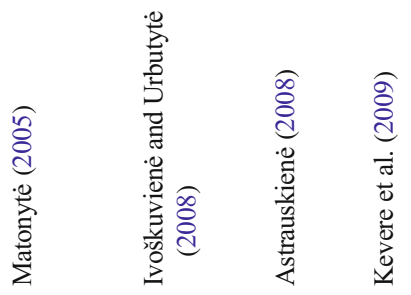

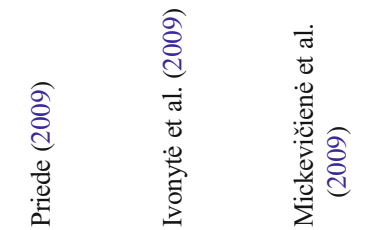




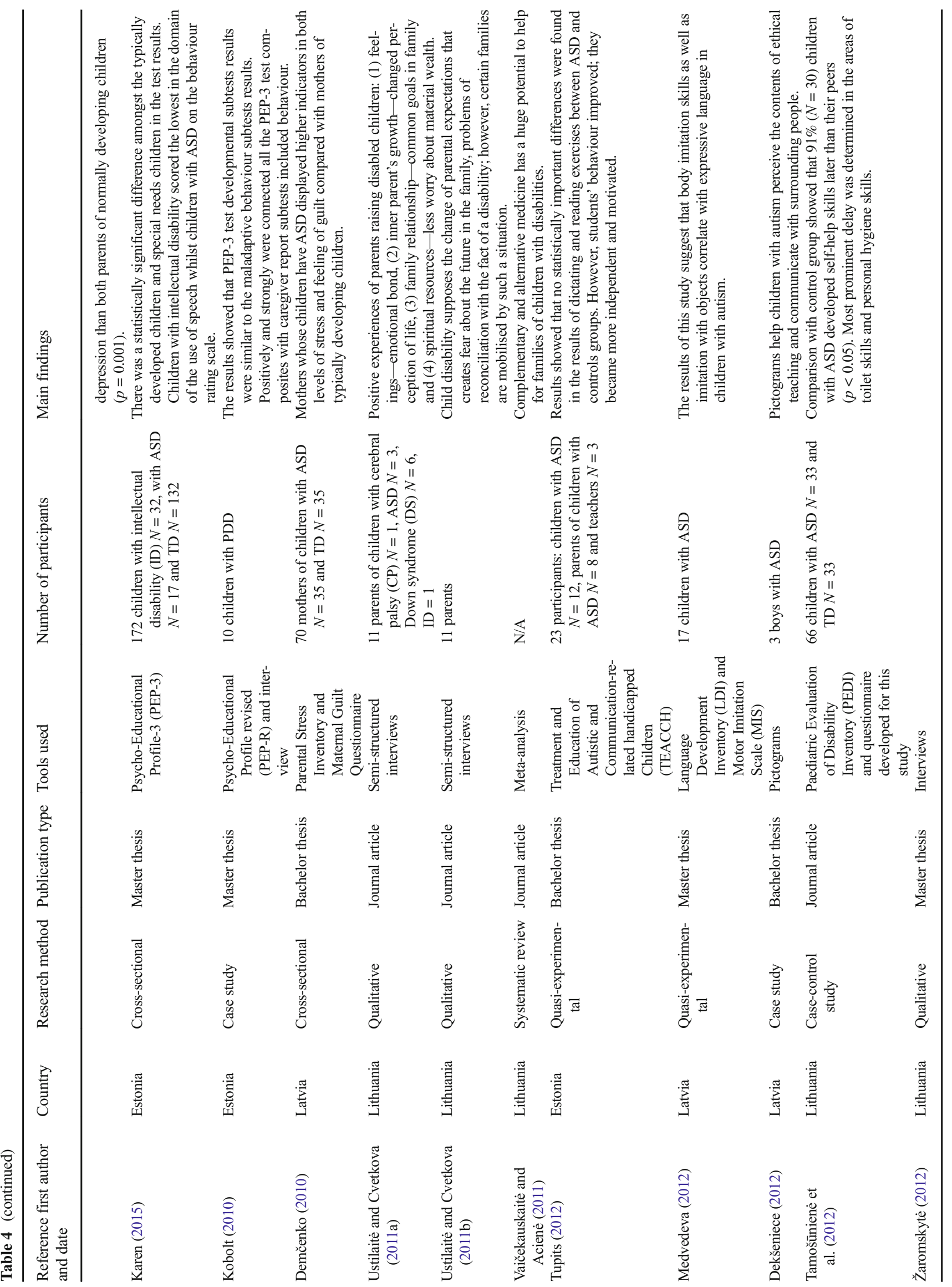




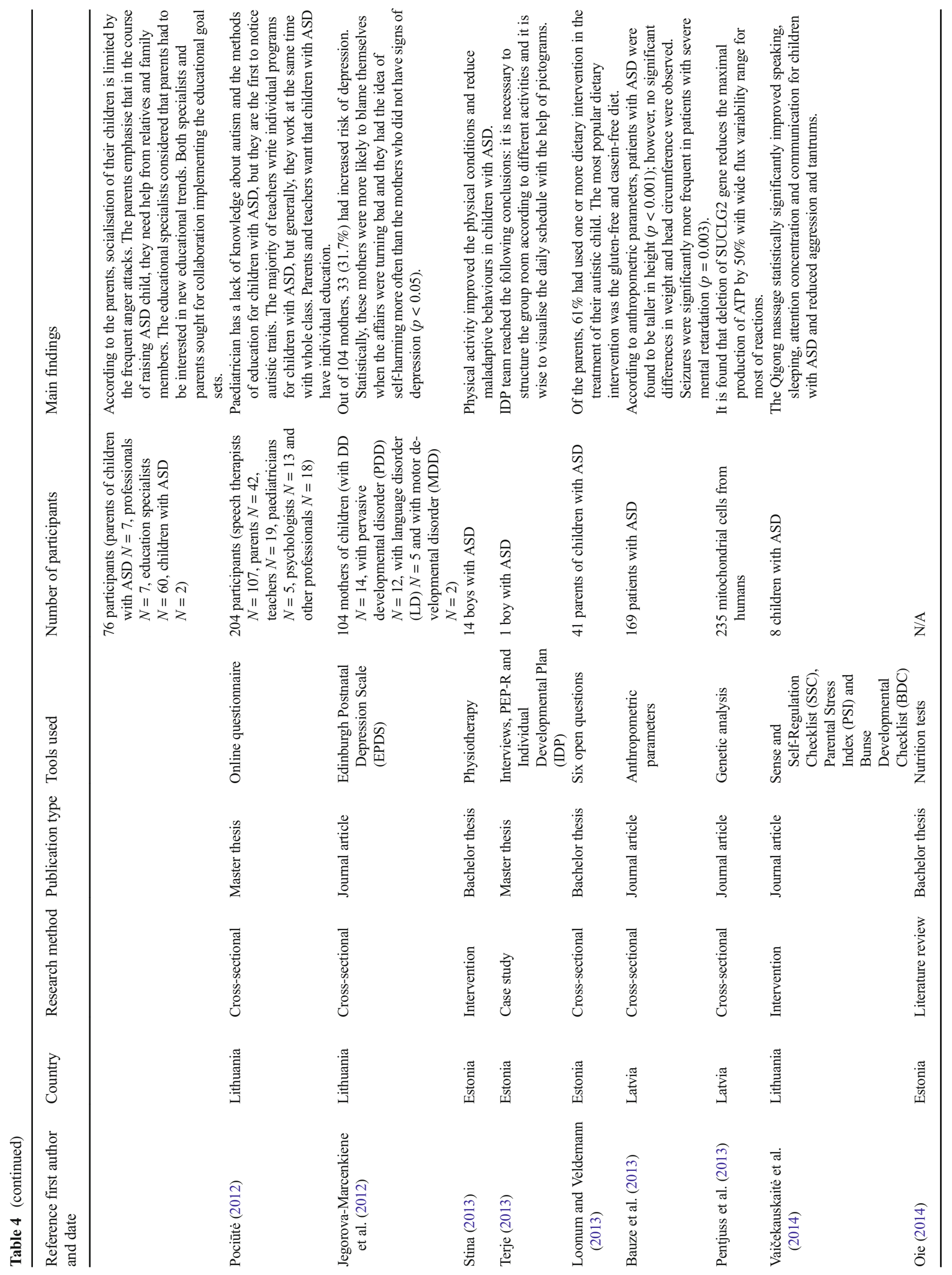




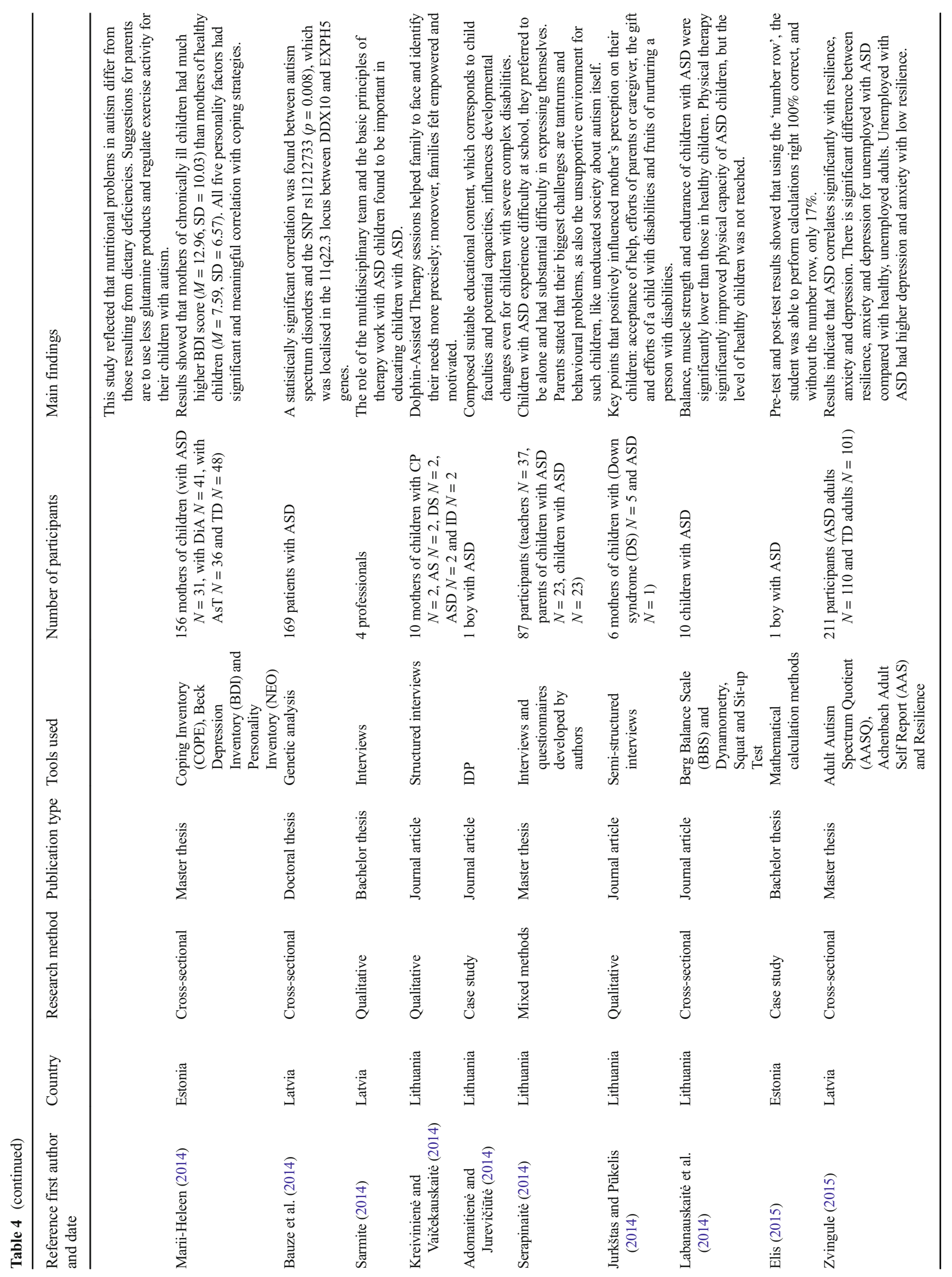




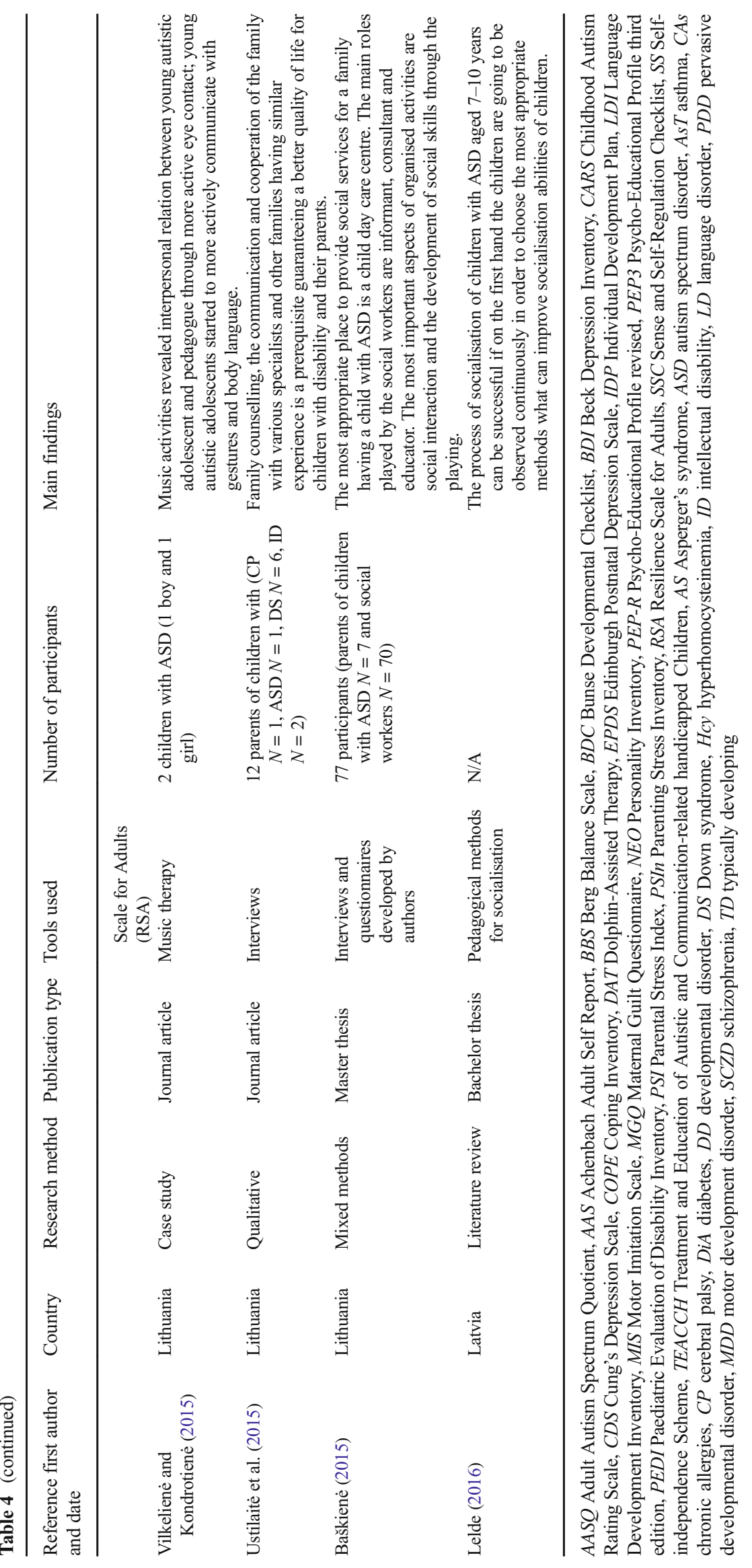


with child's behavioural difficulties. These findings are supported by previous research findings (Sharpley et al. 1997; Hamlyn-Wright et al. 2007).

Another area highlighted in review findings was parenting qualities and skills whilst raising child with autism (Ivoškuvienè and Urbutytè 2008; Ustilaite and Cvetkova 2011a, b; Žaromskytė 2012; Pociūtè 2012; Serapinaitè 2014; Jurkštas and Pūkelis 2014; Ustilaitè et al. 2015). Study by Ivoškuvienè and Urbutyte (2008) stated that mothers use positive affirmation, whilst fathers use punishment and criticism in parenting their child. Research by Lesinskienè (2002) evaluated grandparent's perception of their autistic grandchild and revealed that grandmothers are more positive towards their grandchild than grandfathers. In addition, researches showed that parent's experience difficulty in raising child with autism and require higher levels of support from society (Ustilaite and Cvetkova 2011a, b; Žaromskytė 2012; Serapinaitė 2014; Jurkštas and Pūkelis 2014) and professionals (Pociūtè 2012; Ustilaitè et al. 2015; Baškienè 2015). Despite difficulties in parenting child with autism, there were two studies that concentrated on positive aspects of raising children with autism (Ustilaite and Cvetkova 2011a, b; Labanauskaite et al. 2014).

These findings require further research on possible external factors of stress, depression or anxiety amongst parents of autistic children as causation is yet to be determined. There is lack of studies on coping or protective mechanisms that could be useful in addressing high levels of stress, anxiety or depression in parents of autistic children.

\section{Autistic Adults}

There was only one study of adults with autism (Zvingule 2015), which attempted to define mental health and resilience factors in autistic adult's population. Results indicated that unemployed autistic adults were more anxious and depressed compared to unemployed healthy controls. Also, autistic adults had lower levels of resilience compared with controls. This, scoping review showed that there is a large gap of research about education, work, relationships, personal development or support for autistic adults.

\section{Treatments and Interventions}

We found studies on various alternative therapies and interventions used across three countries such as art (drawing) (Lesinskiene 2002), homoeopathic medicine (Vaičekauskaite et al. 2014), body imitation (Medvedeva 2012), qigong massage (Vaičekauskaitė and Acienè 2013), dolphin therapy (Kreivinienė and Vaičekauskaite 2014), occupational health (Elis 2015) and music therapy (Ustilaite et al. 2015). Results of most therapies showed a statistical significant change in child's behaviour, physical health, self-independence and social skills. It is important to state that homoeopathic medicine was mainly researched for the 'cure' of autism symptoms. This could be explained by the perception of the society that still counts autism as illness that could be 'cured', and alternative medicine is seen as more acceptable than traditional medicine (Mikulènaite and Ulevičiūtè 2004).

Interventions used in these Baltic countries were TEACCH (Tupits 2012), pictograms (Dekšeniece 2012) and physiotherapy (Ivonyte et al. 2009; Stina 2013). Study results showed that there was no significant difference between intervention group and control in reading and dictating when using TEACCH. Whilst study that used pictograms found improvement in communication of children with autism, physiotherapy resulted in advanced selfindependence skills amongst autistic children. Findings about the TEACCH program in the review do not support wider findings on this intervention, which are significant improvement in autistic child's communication and social behaviours (Panerai et al. 2002; Virues-Ortega et al. 2013). It is important to highlight that there is no data on usage of medical treatments that are available in Baltic States.

\section{Strengthens and Limitations}

This scoping review is a first analysis of the situation of autism in Baltic countries. This paper revealed the deficiencies in the research areas and lack of services around autism in Lithuania, Latvia and Estonia. The limitations of this review are the limited access to the papers that are published and the language barrier as some papers were published in the language that authors do not speak: Estonian and Latvian.

\section{Implications}

Review revealed that autism is severely under-researched area in Baltic region. In addition, the epidemiology of the disorder is unknown for Latvia and Estonia. The social aspects of autism, education experience and parenting, are the most intensively researched areas across three countries, whilst medical aspects, treatments, interventions, and services, are severely behind of current research in the world. For the future research, it is important to consider studying lives of adults with autism across Baltic States and also to engage in research on genetic and biological markers of autism and promote randomised control trials on available medical treatments. Finally, the researchers should aim to assess existing interventions and treatment plans in more integrated and universal manner. 
Funding The study was not funded by any grants. This paper is part of doctoral dissertation about parental experiences in raising child with autism spectrum in Lithuania and UK, which is funded by the University of Oxford, Department of Psychiatry.

\section{Compliance with Ethical Standards}

Conflict of Interest The authors declare that they have no conflict of conflict.

Ethical Approval This article does not contain any studies with human participants or animals performed by any of the authors.

Open Access This article is distributed under the terms of the Creative Commons Attribution 4.0 International License (http:// creativecommons.org/licenses/by/4.0/), which permits unrestricted use, distribution, and reproduction in any medium, provided you give appropriate credit to the original author(s) and the source, provide a link to the Creative Commons license, and indicate if changes were made.

\section{References}

Adomaitienè, R. \& Jurevičiūtè, K. (2014). I vaiką orientuoto specialiojo ikimokyklinio ugdymo turinio modelis, [the child-centred preschool special education content model]. Didactics, 9(1), 115-118.

Astrauskienè, G. (2008). Sveiku ir turinčiu autizmo sutrikima —socialinès squeikos, verbalines ir neverbalinès komunikacijos bei elgesio tyrimas// [healthy children and children with autism spectrum-social aspects, verbal and nonverbal communication, and behavioural analysis] (masters of sports pedagogy and psychology). Kaunas: Lithuanian Physical Education Academy.

Baškiene, A. (2015). The formation of the possibilities of social provision for the families bringing up children with autism spectrum disorders. (master of special education). Siauliai: University of Siauliai.

Bauze, D., Kevere, L., Kronberga, Z., Rizevs, A., Dzalbs, A., Daneberga, Z., et al. (2013). The clinical analysis of patients with autism and autism spectrum disorders in Latvia. Proceedings of the Latvian Academy of Sciences. Section B. Natural, Exact, and Applied Sciences, 1(6), 146-163.

Bauze, D., Piekuse, L., Kevere, L., Kronberga, Z., Rizevs, A., Vaivade, I., et al. (2014). Association of single nucleotide polymorphism in chromosome 11 with autism spectrum disorder. Proceedings of the Latvian Academy of Sciences. Section B. Natural, Exact, and Applied Sciences, 67(6), 6-10. doi: 10.2478/prolas-2013-0079.

Dekšeniece, Z. (2012). The use of a pictogram to the ethics training for children with learning disabilities. (bachelor of speech and language therapy). Riga: University of Latvia.

Demčenko, K. (2010). Children with autistic spectrum disorder maternal stress and guilt. (bachelor of psychology). Riga: University of Latvia.

Elis, R. (2015). Calculating the results of one of teaching methodscounting on the fingers ASD child's example. (bachelor of special education). Tartu: University of Tartu.

Emond, A., Emmett, P., Steer, C., \& Golding, J. (2010). Feeding symptoms, dietary patterns, and growth in young children with autism spectrum disorders. Paediatrics, 126(2), 337-342. doi:10.1542/ peds.2009-2391.

Guo, H., Chi, J., Xing, Y., \& Wang, P. (2009). Influence of folic acid on plasma homocysteine levels \& arterial endothelial function in patients with unstable angina. The Indian Journal of Medical Research, 129(3), 279-282.

Hamlyn-Wright, S., Draghi-Lorenz, R., \& Ellis, J. (2007). Locus of control fails to mediate between stress and anxiety and depression in parents of children with a developmental disorder. Autism, 11(6), 489-501. doi:10.1177/1362361307083258.

Ivonytė, R., Kavaliauskienė, G., \& Sąlyga, J. (2009). Veiksnių, darančiu ittaką vaiku, sergančių autizmu, savarankiškumo igūdžiu ugdymui, vertinimas [Evaluation of influence on independence and skills of children with autism] Health Sciences, 19(2), 121-132.

Ivoškuvienè, R. \& Urbutytè, A. (2008). Autistiško vaiko pažinimas šeimoje [Recognition of an autistic child in the family]. Social Science Education, 4(20), 158-163.

Jegorova-Marcenkiene, N., Jasonaite, A., Mikulenaite, L., Lesinskiene, S., \& Petrulyte, J. (2012). Evaluation of emotional state of parents of developmentally disabled children. Health Sciences, 22(6), 4-15.

Jurkštas, S., \& Pūkelis, K. (2014). Pozityvios ittakos veiksniai šeimos nariams, ugdantiems proto negalią turinčius vaikus [positive influence on the family members, who are raising children with mental disability]. SOTER: Journal of Religious Science, 52, 113-126. doi: 10.7220/2335-8785.52(80).7.

Karen, K. (2015). The outcome of PEP-3 test for children with autism spectrum disorders and intellectual disability. (master of special education). Tartu: University of Tartu.

Kevere, L., Purvina, S., Bauze, D., Zeibarts, M., Rizevs, A., Purvins, I., Caune, M. \& Andrezina, R. (2009). Psychiatric disorders in childhood and hyperhomocysteinemia. European Psychiatry, 24(1), 96 101. doi: 10.1016/S0924-338(09)71194-0.

Kobolt, K. (2010). PEP-3 TEST development and assessment for children 3-8 years with autism disorder. (master of special education). Tartu: University of Tartu.

Krasauskaite, L. (2010). Analysis of the social help provided by family support centre for family's raising autistic child. (master of social work and its management). Vilnius: Vilnius University.

Kreivinienè, B., \& Vaičekauskaite, R. (2014). Complementary and alternative medicine: regulation and needs of families of children with disabilities. Public Health, 1(9), 64-78.

Labanauskaite, I., Lileikyte, A., Vasilionytè, A., Dudonienè, V., Urbonavičius, V., Čižauskienè, S., \& Juknevičienè, R. (2014). Impact of physiotherapy on physical capacity of 7-11-year-old children with autism disorder. Journal of Rehabilitation Science: Care, Physiotherapy and Ergo therapy, 2(11), 8-10.

Lelde, A. (2016). The process of socializing 7-10 years old children with autism. (master of sociology). Riga: University of Latvia.

Lesinskienè, S. (2000). Vilniaus miesto vaikų autizmas [Vilnius city children's autism]. (doctoral in psychiatry), Vilnius University. Published in. Journal of Biological Psychiatry and Psychopharmacology, 2, 1-148.

Lesinskienè, S. (2002). Children with Asperger's syndrome: specific aspects of their drawings. International Journal of Circumpolar Health, 2, 7-16.

Lesinskienè, S., Pūras, D., Kajokienè, A., \& Senina, J. (2002a). Aspects of nursing of the autistic children. Medicina, 38(4), 412-419.

Lesinskienè, S., Vilūnaite, E., \& Packevičiūte, B. (2002b). Aspects of the development of autistic children. Medicina, 38(4), 405-411.

Lesinskienè, S., Ranceva, N., Vitkute-Maigiene, L., Stacevic, I., \& Mitrauskas, M. (2008). Dynamics of inpatient child psychiatric care in the time frame 1995-2005. International Journal of Psychiatry in Clinical Practice, 12(8), 247-255.

Loonum, K., \& Veldemann, A. (2013). Parental reports on the efficacy of dietary intervention for their children with autism spectrum disorders. (bachelor of special education). Tartu: University of Tartu.

Mansell, W., \& Morris, K. (2004). A survey of parents' reactions to the diagnosis of an autistic spectrum disorder by a local service: access to information and use of services. Autism, 8(4), 387-407. doi:10. $1177 / 1362361304045213$.

Marii-Heleen, A. (2014). Stress management factors in mothers, who are raising chronically sick children in Estonia. (master of psychology). Tartu: University of Tartu. 
Matonyte, M. (2005). Mothers maternal stress features raising children with developmental problems or suffering from chronic allergic diseases. (master of psychology). Kaunas: University of Vytautas Magnum.

Medvedeva, O. (2012). Imitation skills related to expressive vocabulary of children with autism spectrum disorders at preschool age. (master of speech and language therapy). Riga: University of Latvia.

Mickevičienè, E., Šinkariova, L., \& Perminas, A. (2009). Depression in fathers and mothers of children with autism spectrum disorder. Psychology, 39(11), 19-30.

Mikulènaitè, L., \& Ulevičiūtè, R. (2004). Early age child autism. Vilnius: Open Society Institute, Soros Foundations Network, 1, $35-58$.

Miller, J. W., Nadeu, M. R., Smith, D., \& Selhub, J. (1994). Vitamin B-6 deficiency vs folate deficiency: comparison of responses to methionine loading in rats. American Journal of Clinical Nutrition, 59(5), 1033-1039.

Oie, V. (2014). The essence of autism and treatment using physical therapy and nutritional interventions. (bachelor of psychology). Tartu: Tartu University.

Panerai, S., Ferrante, L., \& Zingale, M. (2002). Benefits of the Treatment and Education of Autistic and Communication handicapped Children (TEACCH) programme as compared with a non-specific approach. Journal of Intellectual Disability Research, 46, 318-327. doi:10.1046/j.1365-2788.2002.00388.x.

Pentjuss, A., Rubenis, O., Bauze, D., Aprupe, L., \& Lace, B. (2013). Flux variability analysis approach of autism related metabolism in stoichiometric model of mitochondria. Bio-systems and Information technology, 2, 37-42. doi:10.11592/bit.131102.

Pociūtè, K. (2012). Children with autism spectrum disorder: individual education needs. (master of special education). Siauliai: University of Siauliai.

Priede, A. (2009). The role of group studies in promoting interaction of preschool children. (master of psychology). Riga: University of Latvia.

Pūras, D., Germanavičius, A., Povilaitis, R., Veniute, M., \& Jasilionis, D. (2004). Lithuania mental health country profile. International Review of Psychiatry, 16(1-2), 117-125. doi:10.1080/ 09540260310001635168.

Querdenker, E. U., \& Meirhofer, K. (2014). Report on international models and standards being focused on the process of vocational integration and the necessary trainings to improve the employability of people with autism spectrum disorder: cases of Estonia, Latvia and Lithuania, 114-122. Retrieved from European Union Lifelong Learning Program. Grutving Projects Publisher: Berlin

Sarmite, B. (2014). Significance of multidisciplinary team, caring for children with autism spectrum disorders. (bachelor of speech and language therapy). Riga: University of Latvia.

Serapinaite, A. (2014). Socialization aspect of adolescents with autism spectrum disorders. (master of special education). Siauliai: University of Siauliai.

Sharpley, C., Bitsika, V., \& Efremidis, B. (1997). Influence of gender, parental health, and perceived expertise of assistance upon stress, anxiety, and depression among parents of children with autism. Journal of Intellectual and Developmental Disability, 22(1), 19-28.
Slay, B. (2009). Poverty inequality and social policy reform in the former Soviet Union. New York: United Nations Report Retrieved: http://www.undp.org/content/dam/rbec/docs/ Poverty-inequality-and-social-policy-reform-in-the-formerSoviet-Union.pdf.

Stina, P. (2013). Asperger's syndrome in childhood: the nature and physiotherapeutic aspects. (bachelor of special education). Tartu: University of Tartu.

Tamošūnienė, J., Mikulènaitė, L., Petrulytė, J., Raistenskis, J., \& Juocevičius, A. (2012). Development of self-help skills of preschool children with autism spectrum disorders. Health Sciences, 22(6), $117-123$.

Terje, K. (2013). Individual development plan implementation for 6-year old boy with autism teaching in kindergarten (master of special education). Tartu: University of Tartu.

Tupits, K. (2012). TEACCHi principles impact of using the autism spectrum disorder pupil's academic performance in Estonia. (bachelor of psychology). Tartu: University of Tartu.

Ustilaite, S., \& Cvetkova, L. (2011a). Positive experience of families raising children with disability. Journal of Pedagogy, 8, 135-142.

Ustilaite, S., \& Cvetkova, L. (2011b). Changes of inner and social life of the families that raise disabled children. Journal of Social Work, 10(1), 69-76.

Ustilaitè, S., Kuginytė-Arlauskienè, I., Cvetkova, L., \& Kalinkevičienė, A. (2015). Message on child's disability and perspectives of development: parents' experiences. Pedagogika, 117(1), 158-167. doi: 10.15823/p.2015.075.

Vaičekauskaite, R., \& Acienè, E. (2011). Šeimos, auginančios vaiką su negalia, sveikatos ištekliu stiprinimas: čigong masažo galimybès [Families raising children with disabilities, strengthening health resources: Chigong massage opportunities]. Health Science, 23(1), 74-78. doi: 10.5200/sm-hs.2013.013 .

Vaičekauskaitė, R., Kreivinienė, B., \& Tilvikas, J. (2014). Preconditions and possibilities for integration of CAM and traditional medicine: situation of families of children with disabilities. Health Sciences, 24(4), 38-43. doi:10.5200/sm-hs.2014.066.

Vilkelienė, A., \& Kondrotienė, E. (2015). Music activity as a communication tool for young autistic adolescents. Pedagogika, 117(1), 185197. doi:10.15823/p.2015.077.

Virues-Ortega, J., Julio, F. M., \& Pastor-Barriuso, R. (2013). The TEACCH program for children and adults with autism: a metaanalysis of intervention studies. Clinical Psychology Review, 33(8), 940-953. doi:10.1016/j.cpr.2013.07.005.

Whiteley, P., Haracopos, D., Knivsberg, A.-M., Reichelt, K. L., Parlar, S., Jacobsen, J., et al. (2010). The ScanBrit randomised, controlled, singleblind study of a gluten- and casein-free dietary intervention for children with autism spectrum disorders. Nutritional Neuroscience, 13(2), 87100. doi:10.1179/147683010X12611460763922.

Žaromskyte, O. (2012). Cognition of autistic preschool children. (master of special education). Siauliai: University of Siauliai.

Zvingule, S. (2015). Symptom correlations of autism spectrum disorder with unemployment duration, resilience, anxiety and depression for unemployed. (master of psychology). Riga: University of Latvia. 